\title{
Russian impact on northern Khanty conditional sentences
}

\author{
Mária Sipos \\ Research Institute for Linguistics, Hungarian Academy of Sciences \\ Budapest
}

\section{Introduction}

As has been shown in numerous investigations of language contact, the borrowing of function words, specifically, conjunctions, may have syntactic consequences. At the same time, it is often emphasised that borrowing grammatical elements and following syntactic patterns do not necessarily correspond (Aikhenwald 2008: 15).

The present paper surveys the patterns conveying conditional content in Synya Khanty (Ob-Ugric, Uralic) texts, as well as the proportion of conditional sentences contaning the Russian conjunction jesli is discussed in the context of its present day role and occurrence of the Khanty marker of conditional sentence.

When talking about the impact of language contacts, following Matras \& Sakel's terminology (2007b), MAT (matter) and PAT (pattern) borrowings, which denote the two basic ways of borrowing (Sakel 2007b: 15), are differentiated.

We speak of MAT-borrowing when morphological material and its phonological shape from one langugage is replicated to another language. PAT describes the case where only the patterns of the other language are replicated, i.e. the organization, distribution and mapping of grammatical or semantic meaning, while the form itself is not borrowed (Sakel 2007b: 15).

The relation of the two concepts has been investigated in numerous case studies (Aikhenwald 2008: 16, Grenoble 2000: 109-110), and it has also been emphasised that PAT borrowing is possible without MAT borrowing (Aikhenwald 2008: 15).

In Finno-Ugric linguistics, it is MAT borrowings that were generally collected, whereas for a long time the syntactic consequences of language contacts were much less often researched. Thus, it has been well known for decades that Finno-Ugric languages had borrowed a lot of conjunctions from Russian (see e.g. Maytinskaya 1983; Alvre 1983; Leinonen 2002). Maytinskaya (1983: 187) listed the Russian loan 
conjunctions that were present in the majority of the Finno-Ugric languages of the Soviet Union: $i$ 'and', $a$ 'but', ili 'or', no 'but', jesli 'if', što 'that'. Besides these, numerous Finno-Ugric languages also borrowed khotja 'although', libo 'or', štoby 'so that'. Alvre (1983) published a similar list of the borrowings of the Baltic Finnic languages, thus the lists in these two papers have been cited since then (Leinonen 2002: 254-255; Rießler 2007: 241).

In the investigated texts, there are more than thirty function words borrowed from Russian, among which conjunctions, several types of adverbs etc. can be found. As for conjunctions, the following appear: (subordinate) što 'that', štoby 'so that', jesli 'if'; coordinate: $i$ 'and', $a$ 'but', ili 'or', no 'but'. As kak budto 'as if' only appears in one single sentence, we cannot exclude that it is a result of code switching. Compared to the frequency of the rest of conjunctions, the number of the occurence of ili 'or' is greater by orders of magnitude due to the fact that the favourite expression of the speaker to display uncertainty is ili mŭj 'or what', where it has a grammatical role other than linking clauses.

As has been mentioned, conditional jesli is also among the loan conjunctions in Khanty. In northern Khanty, where - as opposed to the southern and eastern dialect groups (Riese 1984: 101-113) - conditional relations are expressed with subordinate sentences without conjunctions, the intrusion of Russian jesli can indeed be foretold with much certainty. Conversely, in the chapter on northern Khanty Riese does not mention jesli. First, among the reasons must be the fact that the sources processed by Riese (1984) reflect the language of a period 2-8 decades earlier. Second, ideals and considerations behind the publication of linguistic material were quite different in the first half of the $20^{\text {th }}$ century, therefore fieldworkers might have been attracted to "pure" Khanty language displaying no Russian impact. Third, folk genres, although not excluded, are less likely to use Russian borrowings than spoken Khanty.

At the same time, the conjunction in question does not occur in Éva Schmidt's Kazym Khanty texts collected in the 1990s and published in the 2000s (Khomlyak 2002). Among these texts there are not only folk tales or songs but also spontaneous texts, which, although undoubtedly having been told several times, still lack expressions characteristic of folk genres, furthermore, they exhibit a considerable number of Russian loans. As Éva Schmidt's intention was to produce an authentic written version of the speech production of the speakers influenced by neither grammatical nor dialectal expectations, it seems probable that in the northern dialects, or at least in the language of her speakers, the conditional conjunction of Russian origin had no special importance. 
There are numerous classifications and categorisations of conditional sentences, e.g. on the basis of logic or linguistics. The aspect of reality of conditional content is also often discussed. In the literature, there is an abundance of terms referring to the two main types of conditional sentences i.e. factual vs. counterfactual, sentences of open vs. rejected condition, realis vs. irrealis (e.g. Riese 1984: 16). Furthermore, formal linguistic characteristics such as markedness, markers, order of clauses, the presence or lack of subordinators or correlatives, the use of tenses etc. are investigated. In the present paper my aim is to survey the markers of northern Khanty conditional sentences occuring in the speech production of a single speaker, in the context of Russian impact on the Khanty language. The tense of the sentences, the position of the Khanty conditional particle $k i$, as well as the ordering of clauses are outside the scope of this research. Considering the fact that the conditional sentence type expressing the unreal condition scarcely appears in texts, the focus of the present paper is the formation of sentences expressing real conditions in the northern Khanty dialects.

The paper aims at answering the following questions:

1. To what extent is the Russian conjunction jesli present in Khanty conditional sentences?

2. Is there any difference in the use of conditional sentences between the traditional northern Khanty texts and the spontaneous speech production of a present-day bilingual speaker?

3. Are there double marked sentences, i.e. ones containing conjunctions of both Russian and Khanty origin, in great number in the corpus?

4. What is the proportion of sentences (i) following the traditional Khanty pattern vs (ii) innovative constructions?

The paper investigates the conditional sentence patterns in the following steps. First, the Khanty language, the linguistic material, and the speaker are introduced (in Sections 1-3). Then the typical forms of conditional sentences in the Khanty and Russian languages are summarised (see Section 4). Section 5 describes the conditional sentences types appearing in the corpus. Results and conlusion are summarised in the final section (6). ${ }^{1}$

\footnotetext{
${ }^{1}$ I am also grateful to an anonymous reviewer, who greatly helped me to improve my paper with numerous valuable comments.
} 


\section{The Khanty language}

Khanty is spoken in the Khanty-Mansi Autonomous District and the Yamalo-Nenets Autonomous District, and in the Tomsk Oblast, in Western Siberia, Russia. According to the 2010 Russian census, the ethnic population amounts to 30,900 , while Khanty is spoken by only 9,580 speakers (Ethnologue ${ }^{2}$ ). The Khanty language has three dialect groups and a large number of subdialects which differ significantly from each other. Consequently, northern, southern (extinct), and eastern Khanty are often considered closely related yet separate languages. The variety to which the texts of the present investigation belong to is spoken by the Synya River, a western tributary of the $\mathrm{Ob}$ River, and is very close to the lects spoken in the following settlements along the western banks of the Ob River: Muzhi, Khantymuzhi, Vosyakhovo, Ust'-Voykar, Unselgort, and Shuryshkary.

An agglutinative language, Khanty employs SOV word order. On the basis of old folklore texts, it was considered to use nonfinite subordination as opposed to finite subordinate sentences, the latter being relatively new: especially finite subordinate sentences with conjunctions have begun to develop in recent times (Schmidt 2008: 49).

\section{On the speaker, data, and corpus}

The investigations are carried out on the basis of the Khanty text material that was collected by Ruttkay-Miklián as a result of fieldwork with a Synya Khanty speaker in the 2000s.

The speaker was born in 1946 in a village by the upper Synya, and she did not leave this region during her life. Similarly to her husband, she spoke the Synya subdialect of northern Khanty. Having been widowed, she raised her children alone, and moved to the regional centre, Ovgort, where she came into contact with a less traditional world. Her language is therefore not archaic but represents the knowledge of a Khanty living in a bilingual settlement, speaking her dialect very well, and having proficiency in Russian at the same time (for further details, see RuttkayMiklián 2008).

In the course of data collection, the speaker was asked to explain the meaning of given words, as well as to give examples in order to reveal each word's meaning, or to describe the use of the word. Furthermore, she had to produce every utterance

\footnotetext{
${ }^{2}$ http://www.ethnologue.com/country/RU/languages
} 
intuitively, not being influenced by either linguistic or ethnographic expectations, i.e. neither the dictionary, nor the fieldworker. With this method, the whole northern Khanty material, especially the Synya Khanty entries, of Steinitz' dictionary (Steinitz 1966-1988) was processed by Ruttkay-Miklián, and this resulted in a 70hour audio recording. The transcribed version of the audio recordings, which amounts to about 127,200 words, was not corrected or edited later either, so the linguistic material can be characterised as spontaneous speech consisting of texts of different length. It contains self-corrections, hesitations, fillers, contracted forms, ellipsis, repetitions, non-standard grammar etc., which might have importance when researching certain features of language use (Grenoble 2012: 102). ${ }^{3}$

\section{Conditional sentences in the Khanty and Russian languages}

\subsection{Types of conditional sentences}

Every language is able to express conditional content, i.e. condition-consequence relation of two events, facts, or factors etc.

The diversity of conditional sentences in the languages of the world originates in the different degrees of markedness, and the great number of the possible markers range from parataxis, in which the conditional relation of the unmarked clauses is suggested by the context, to the multiple marking of the conditional relations (through conjunctions, correlatives, tenses etc.) (Bakró-Nagy 2008; Veltmann 1994: 683). In this paper, a relatively broad definition is used, viz. in the conditional construction there is a statement (Lat. apodosis, Eng. consequent) whose realization depends on the fulfilment or the verity of the other part of the construction (Lat. protasis, Eng. antecedent) (Bakró-Nagy 2006: 1, Veltmann 1994: 683).

The texts being examined are definitely of descriptive character, the conditional sentences mainly present implications between facts, thus the use of rejected conditional sentences is not characteristic of them.

\subsection{Conditional sentences in northern Khanty}

In his monograph, Riese (1984: 102) characterises the conditional sentences of northern Khanty in the following way (confining the linguistic forms mentioned in the original to Synya Khanty elements). The sentences of open condition can be

\footnotetext{
${ }^{3}$ I am grateful to Eszter Ruttkay-Miklián for making her text collection, with its English and Hungarian translations, available for me.
} 
expressed in three ways (in the clause containing the apodosis there is no correlative):

A. [protasis with the conditional particle $k i$ ' 'if'] + [apodosis];

B. [protasis with neither a conditional particle nor conditional conjunction] + [apodosis]; ${ }^{4}$

C. [protasis with the conjunction xundi / xun 'when', xundi-ki 'if'] + [apodosis].

The above types (as for $\mathrm{C}$, subtypes are due to different conjunctions) are illustrated below.

In sentence (1), the protasis contains the conditional particle $k i$ 'if':

$$
\begin{aligned}
& \text { ope-n-ng esamjink-ən ăt ki jeś-l-a, } \\
& \text { daughter-2SG-LOC milk-LOC NEG COND drink-PRS-PASS } \\
& \text { ma pošx-em-a mij-i! } \\
& 1 \mathrm{SG} \text { child-1SG-LAT give-IMP2SG }
\end{aligned}
$$

(Steinitz 1975: 149, cited by Riese 1984: 103)

A paratactic conditional sentence can be seen in (2):

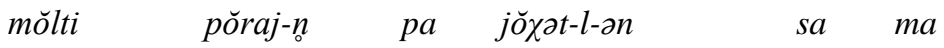

$$
\begin{aligned}
& \text { some.kind.of time-LOC again come-PRS-2SG PTCL 1SG }
\end{aligned}
$$

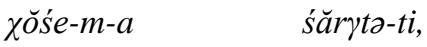

$$
\begin{aligned}
& \text { PPOS-1SG-LAT make.shaman.foretell-INF }
\end{aligned}
$$

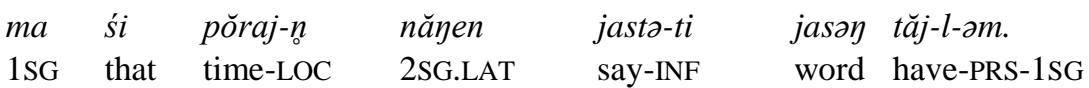

'Wenn du irgendwann mal wieder zu mir kommst, mich schammanaisieren zu bitten, dann werde ich ein Wort mit dir zu sprechen haben' [If, sometime, you come to listen to my predictions, then I will have something to say to you]'

(Steinitz 1975: 73, cited by Riese 1984: 104)

The following conditional sentence ${ }^{5}$ (3) contains the conjunction $\chi u n(\chi q n)$ :

\footnotetext{
${ }^{4}$ This structure is also called paratactic. In paratactic conditional sentences, the relationship of the clauses is inferred from the text.

${ }^{5}$ The sentence is from a text from Kazym Khanty, which is, similarly to Synya Khanty, belongs to the northern Khanty dialects. The word $\chi u n$ 'where' is thus spelt $\chi q n$ here, and $A$ is also characteristic of the Kazym dialect.
} 
(3)

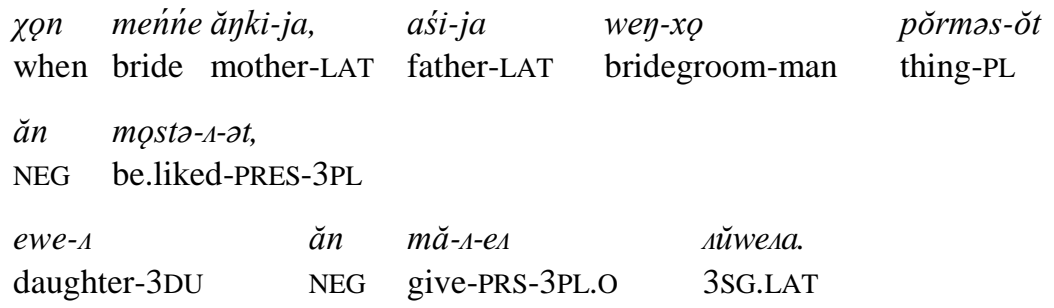

'Wenn die Gegenstände des Brätigams der Mutter un Vater der Braut nicht passen, geben sie ihm ihre Tochter nicht. [If the mother and father of the bride do not like the gifts of the bridegroom, they do not give him their daughter.]'

(Rédei 1968: 44; cited by Riese 1984: 106)

In sentence (4), there is a compound conjunction consisting of an interrogative / relative pronoun $\chi u n d i$, which is the equivalent of $\chi u n$ 'when' in the northernmost Khanty dialects and the conditional particle $k i$ 'if':

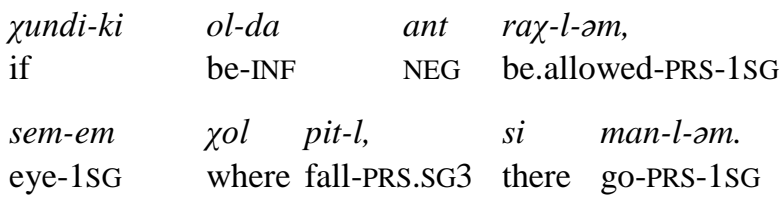

'Ha pedig majd itt nem maradhatok tovább, amerre a szemem lát [tkp. esik], arra megyek. [If I cannot remain here any longer, I will go wherever I throw my glance]'

(Pápay 1910: 91; cited by Riese 1984: 106)

Among the above mentioned structures, the unmarked paratactic structure seems to be original, in which the order protasis + apodosis is, of course, dominant. It is also well known that the conditional particle ke/ki of the Khanty and Mansi languages was borrowed from Komi. The particle $k i$ can occur in almost any position in the sentence except in the clause initial one, although the most frequent position for this particle in Khanty is the clause final position, or the one preceding the predicate. In the case of the order protasis + apodosis, the particle $k i$ obligatorily appears in the sentence. In the northern Khanty dialects surveyed by Riese (1984), the sentences containing $k i$ greatly outnumber the rest of the types of conditionals, i.e. they make the $89 \%$ of total (Riese 1984: 101-106). 


\subsection{Conditional sentences in Russian}

Conditional in Russian is expressed with a complex sentence consisting of a conditional clause (protasis) and a subjunctive clause (apodosis). ${ }^{6}$ The typical conjunction (occuring in clause initial position) is если бы or если depending on the type of conditional. If it expresses unreal condition, i.e. the action in the subjunctive clause cannot take place because the condition in the conditional clause cannot be realized, then it will begin with the conjunction если бы, followed by the verb in the past tense. The subjunctive clause has a verb in the past tense and the particle $\sigma b l$ (Mitrevski) (5):

$\begin{array}{llll}\text { Если он разбуд-ит } & \text { жен-y, } & \text { она } \\ \text { if he.M wake-3SG.PRS } & \text { wife-ACC } & \text { 3SG.F } \\ \text { pacсерд-иm-ся. } & & \\ \text { get.angry-3SG.PRES-REFL } & \end{array}$

'If he wakes his wife, she will be angry.'

(Wade 2011: 333)

The sentence can begin with either clause (6) (7) (Mitrevski):

\begin{tabular}{|c|c|c|c|c|c|}
\hline $\begin{array}{l}\text { Если } \\
\text { if }\end{array}$ & $\begin{array}{ll}\text { 6bl } & y \\
\text { PTCL } & \text { PREP }\end{array}$ & $\begin{array}{l}\text { меня } \\
1 \mathrm{SG}\end{array}$ & $\begin{array}{l}\text { был- } и \\
\text { be.PST- }\end{array}$ & & $\begin{array}{l}\text { деньги, } \\
\text { money }\end{array}$ \\
\hline $\begin{array}{l}\text { noexa } \\
\text { travel }\end{array}$ & $\begin{array}{l}-\pi \\
-P S T . S G . M\end{array}$ & $\begin{array}{l}\text { бbl } \\
\text { PTCL }\end{array}$ & $\begin{array}{l}\text { Ha } \\
\text { PREP }\end{array}$ & $\begin{array}{l}\text { roz. } \\
\text { south }\end{array}$ & \\
\hline
\end{tabular}

$\begin{array}{llllll}\text { Я } & \text { поеха-л } & & \text { бы } & \text { на } & \text { юг, } \\ \text { 1SG } & \text { travel-PST.SG.M } & \text { PTCL } & \text { PREP } & \text { south } \\ \text { если } & \text { б } \quad \text { y } \quad \text { меня } & \text { был- } u & \text { деньги. } \\ \text { if } & \text { PTCL } & \text { PREP } & \text { 1SG } & \text { be.PST-PL } & \text { money } \\ \text { 'I would go to the south if I had money.' }\end{array}$

(Mitrevski)

Russian also has conditional expressions with conditional clauses that are realizable; these complex sentences do not use the particle $\sigma \mathrm{bl}$. In these sentences,

\footnotetext{
${ }^{6}$ The formation of Russian conditional sentences is summarised on the basis of Wade 2011 and Mitrevski http://www.auburn.edu/ mitrege/russian/tutorials/0048.html.
} 
the condition in the conditional clause upon which the situation in the main clause depends is possible and realizable (8) (9).

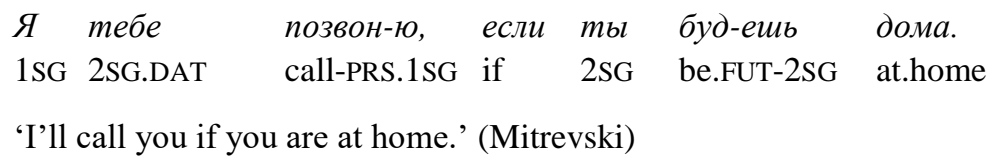

\begin{tabular}{|c|c|c|c|}
\hline $\begin{array}{l}\text { Если } \\
\text { if }\end{array}$ & $\begin{array}{l}6 \\
\text { b }\end{array}$ & $\begin{array}{l}n \\
-3 S G\end{array}$ & $\begin{array}{l}\text { хорош-ая } \\
\text { good-F }\end{array}$ \\
\hline$M b l$ & поед-ем & B & парк. \\
\hline PL & go-1PL & PREP & park \\
\hline
\end{tabular}

'If the weather is nice, we'll go to the park.'

(Mitrevski)

As for the previous type of conditional clauses, i.e. those expressing unreal condition, it allows two kinds of interpretations (Wade 2011: 333) (10):

$\begin{array}{lllllll}Я & \text { пошё-л } & \text { бы, } & \text { если } & \text { был } & \text { меня } & \text { пригласи-ли. } \\ \text { 1SG } & \text { go-3SG.M } & \text { PTCL } & \text { if } & \text { PTCL } & \text { 1SG.ACC } & \text { invite-PL.PST }\end{array}$

'I would go if they invited me.'

'I would have gone if they had invited me.'

(Wade 2011: 333)

\subsection{Borrowing foreign forms and patterns}

Foreign forms and patterns make their way into the target language in several different ways (Aikhenwald 2008: 22-26). It can be a form simply transferred from one language into another one, there may be an enhancement of an already existing feature, extension by analogy, reinterpretation and reanalysis, areally induced grammaticalization, grammatical accommodation, or loan translation. Finally, lexical or grammatical parallelism is mentioned by Aikhenwald, which means that between typologically different languages it may happen that the pattern of the target language and that of the source language appear in one and the same clause / sentence (Aikhenwald 2008: 25). By means of a representative example in Tetun Dili (a Tetun based creole language in East Timor), which is in contact with Portuguese, Hayek (2008: 170) presents a stage named lexical pairing by him, in which "native and borrowed elements appear optionally together". The structure combining two patterns "allows a smooth transition from the older native structure to the newer, less complex one" (Hajek 2008: 170). 
There are examples of similar mechanisms in Finno-Ugric languages as well (see Kaysina 2013, Tánczos 2013, Sipos 2014). Among these we can find cases where the conjunction of Russian origin appears in clause-initial position while the (original) conjunction of the target language, with a similar function, can also be found in the sentence, in a different position Jefremova 2013: 188; Kaysina 2013: 140; Tánczos 2013, Sipos 2014: 90-92). A similar phenomenon can be observed in the case of the conditional particle borrowed from Russian and the particle $k i$ 'if' in Khanty.

In what follows, I will discuss the conditional structures and their diversity in the examined texts.

\section{Conditional sentences in the corpus}

Due to the descriptive and explanatory character of the corpus, the conditional sentences appearing in it in great number express general truths, facts about natural, psychological or social phenomena that always take place in similar ways, events with the if-then logical relation between them.

In the texts elicited from Ruttkay-Miklián's speaker, numerous types of sentences expressing conditional content can be observed. First, there is an abundance of examples of paratactic constructions, as well as sentences containing the Khanty particle ki. Second, there are clauses introduced by the conjunction of Russian origin. Furthermore, there are clauses containing the conjunction of Russian origin and the common Khanty conditional particle at the same time (jesli... ki). In addition to these, the same pattern can be found introduced by the following Khanty

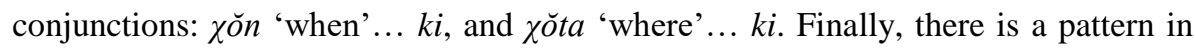
the corpus in which the conditional particle $k i$, which, normally, can never be found in clause initial position, shows up in both intitial and final positions in the clause at the same time $(k i \ldots k i)$. The sentence type described by Riese, in which the conjunction is $\chi \breve{u n}$ 'when', does not occur in the corpus. I will now discuss these structures in detail.

\subsection{Paratactic constructions}

In paratactic constructions, the relation of the two clauses is merely logical, i.e. conditionality is not marked grammatically. This is why the typical order is protasis + apodosis, see (11)-(12): 
$\begin{array}{lllllll}\text { (11) } \breve{\chi} \chi \text { ăntom in, } & \text { wan, letŏt } \breve{\text { - }} \text { ti } & \text { sir-en } & \text { ăntəm. } \\ \text { money NEG now look food buy-INF } & \text { way-2SG } & \text { NEG }\end{array}$

'If you haven't got money now, look, you can't buy food.'

(Ruttkay-Miklián 2010)

$\begin{array}{llllll}a & p a & \text { sir-ən } & \text { jasti-l-a, } & \text { sit } & \text { atวm jasəy. } \\ \text { but } & \text { different } & \text { way-LOC } & \text { say-PRS-SG3.PASS } & \text { it } & \text { bad }\end{array}$

'But if it is said in another way, it's a nasty word.'

(Ruttkay-Miklián 2010)

\subsection{Sentences containing the conditional particle}

In both language materials, i.e. in those investigated by Riese as well as in the texts produced by Ruttkay-Miklián's speaker, the most frequent sentence type is the one with a protasis containing the Khanty conditional particle $k i(13)$ :

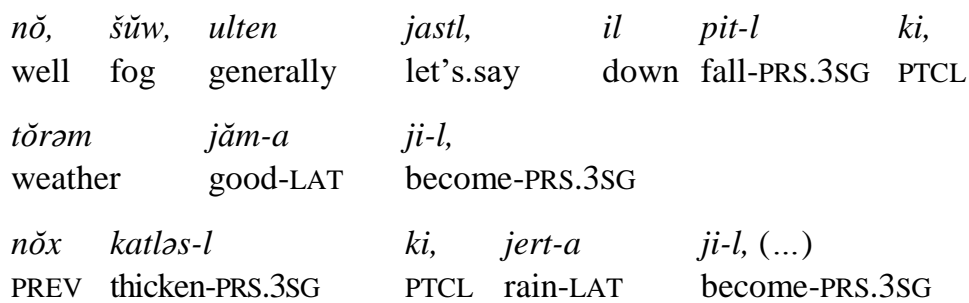

'Well, generally the fog, let's say, if it falls, the weather will be good, if it thickens, it will rain...'

(Ruttkay-Miklián 2010)

However, it should be noted that besides being the marker of conditional content in the protasis, the particle $k i$ has a further function in Khanty, as it can also express uncertainty and low probability. Still, the two functions can easily be differentiated.

This modal use can be observed in the situations when the speaker was not sure whether she understood the word she had to explain, or whether she was able to give a sketch of its meaning or use, i.e. the wording expresses a kind of uncertainty. One of the numerous sentences of this type is (i):

(i) sit moś jasəy ki.

that tale word PTCL

'It might be a tale-word.'

(Ruttkay-Miklián 2010) 
Similarly, in the following example, $k i$ suggests uncertainty. It is suitable for illustrating the function in a question as the sentence expresses deduction ('it was cold when you arrived, mosquitos might have died'), but not condition + consequence (*'it was cold when you arrived, if there were no mosquitos') (ii):

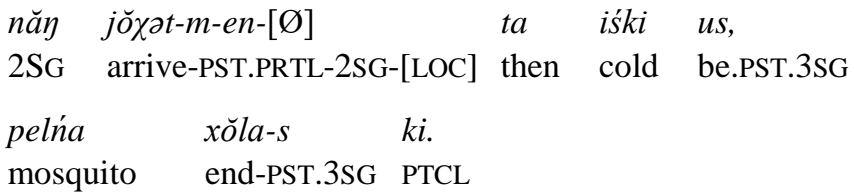

'When you arrived it was cold, the mosquitos must have ended!'7

(Ruttkay-Miklián 2010)

In this function, it also appears in code-switching sentences, as in (iii)-(iv):

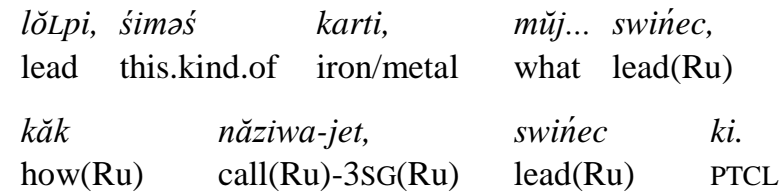

'Lead, a kind of metal, what... lead, what is it called, maybe lead.'

(Ruttkay-Miklián 2010)

(iv) sŏwa tăm mŭj,

gizzard this what

năwrena(!) kăk eta počkaj-en $\quad$ iti $\quad k i$, $\operatorname{probably}(\mathrm{Ru})$ as $(\mathrm{Ru})$ this $(\mathrm{Ru}) \quad \operatorname{kidney}(\mathrm{Ru})-2 \mathrm{SG}$ in.the.way.of PTCL

'What is a gizzard, most likely it is like this kidney maybe, (...)'

(Ruttkay-Miklián 2010)

\footnotetext{
${ }^{7}$ The context of this sentence is the following: "The other day you went to the village, don't those people use net tents? Now the mosquitos are gone, I guess. Yes. They don't use them. In the summer it is full of mosquitos, they must use them. When you arrived it was cold, the mosquitos must have left! That's why they don't have net tents there." The conversation is undoubtedly about the possible causes of why the fieldworker is not familiar with net tents against mosquitos, i.e. the topic of this speculation is not the weather. This is why the interpretation, otherwise seeming possible, 'It must have been cold when you arrived, if there weren't any mosquitos' can be excluded. I am grateful to my anonymous reader for warning me about this ambiguity.
} 
In order to survey the proportion of these two functions, the two types of its appearance have been counted in a section of the whole text, i.e. in the comments belonging to the dictionary entries beginning with $s$. It amounts to 19 full pages, the number of words is ca. 13,500, where $k i$ functions as a conditional particle in 58 sentences, while in 24 cases it is used for expressing probability.

\subsection{Conditional conjunction borrowed from Russian}

In a further type of conditional sentences, illustrated in (14) below, a clause containing the conjunction of Russian origin can be seen, where apodosis precedes protasis. In case of this ordering, conditional relation must be grammatically marked (NB: this is the only example of this clause order):

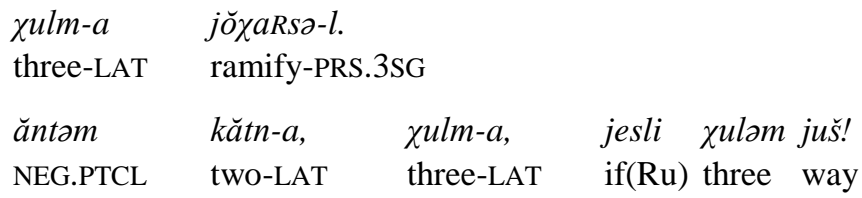

'[the road] goes into three directions. Not into two but three, if it's three roads.'

(Ruttkay-Miklián 2010)

\subsection{The conditional conjunction and the conditional particle occuring together}

\subsubsection{The Russian conjunction jesli + Khanty particle $k i$}

The conjunction jesli also appears in sentences containing the conditional particle $k i$. The sentence in (15) is not a prototypical conditional sentence but it illustrates the broad semantic area between conditionals and time clauses:

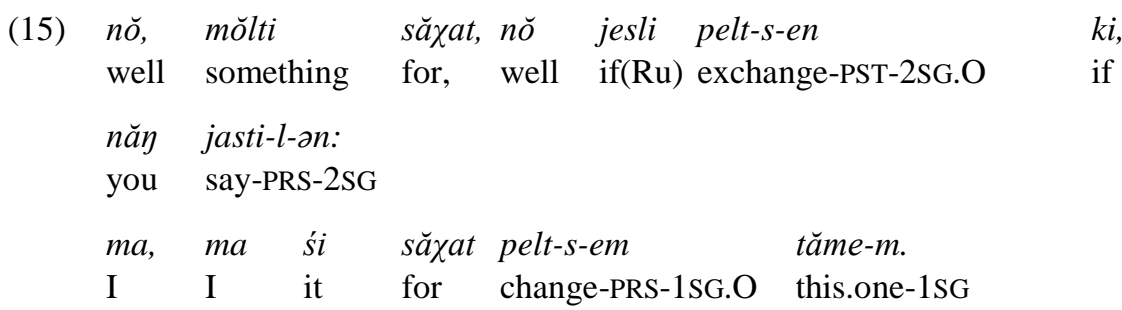

'Well, for something, well, if you exchanged it you say: I've exchanged this for that.' 


\subsubsection{Khanty conjunction $\chi \breve{o n}+$ Khanty particle $k i$}

The particle $k i$ can also occur within the same clause with Khanty conjunctions as well. As the semantics of conditional sentences and time clauses cannot always be easily differentiated as can be observed in numerous languages, the occurrence of

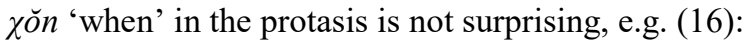

\begin{tabular}{|c|c|c|c|c|c|}
\hline 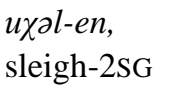 & $\begin{array}{l}l \breve{w} w \\
\text { it }\end{array}$ & $\begin{array}{l}\chi \breve{o n} \\
\text { when }\end{array}$ & $\begin{array}{l}\text { lopas-en } \\
\text { pantry-2SG }\end{array}$ & $\begin{array}{l}\text { jem } \\
\text { prohibition }\end{array}$ & $\begin{array}{ll}k i & \breve{a} t \\
\text { PTCL } & \text { NEG }\end{array}$ \\
\hline $\begin{array}{l}\text { tăj-l, } \\
\text { have-PRS.3SG }\end{array}$ & $\begin{array}{l}n \check{~} \\
\text { well }\end{array}$ & $\begin{array}{l}\text { nŏ } \\
\text { up }\end{array}$ & $\begin{array}{l}\chi u \chi-t i \\
\text { climb-INF }\end{array}$ & $\begin{array}{ll}k i & \breve{a} t \\
\text { PTCL } & \text { NEG }\end{array}$ & 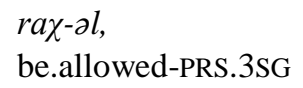 \\
\hline
\end{tabular}

'The sleigh, if the pantry is not forbidden, well, if you can't climb on it, look, you stand your sleigh there.'

(Ruttkay-Miklián 2010)

As Pápay's texts indicate (Riese 1984: 105), in the northernmost Khanty dialects there is a compound conjunction $\chi u n d i-g i$ 'if'. It consists of the same elements, i.e. xunti in the Obdorsk subdialect is the equivalent of the Synya Khanty interrogative and relative pronoun $\chi \breve{o n}$ 'when'; while $g i$ is the Obdorsk equivalent of Synya Khanty $k i$ 'if' with a voiced consonant. However, the syntactic environment, i.e. the positions of ki/gi in the clause, might have differed from present-day Synya Khanty patterns. The way of development in the case of the Obdorsk Khanty conjunction is out of the scope of the present paper.

As has already been mentioned, the borderline between time clauses and protases may not be semantically clear, consequently the occurence of $k i$ in a clause containing the conjunction $\chi \breve{o n}$ ' when' is not surprising (17):

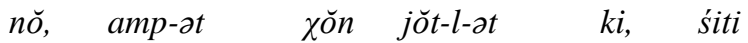

$$
\begin{aligned}
& \text { well dog-PL when play-PRS-3PL PTCL in.this.way } \\
& \text { jast-l-a, atom torram-a ji-l. } \\
& \text { say-PRS-PASS.3SG bad weather-LAT become-PRS.3SG } \\
& \text { 'When dogs play, they say we'll have bad weather.' }
\end{aligned}
$$

(Ruttkay-Miklián 2010)

Although the next sentence (18) can be interpreted in two ways (a-b), it should also be classified in the transitional category described above:

(a) 'When a rope is cut, (then) you tie them, (and) - you say - "I bind them"'; 
(b) 'When a rope is cut (and) you tie them, then - you say - "I bind them"'.

$\begin{array}{llll}\chi \breve{o n} & k e l & \text { to } \chi \text {-əl } & k i \\ \text { when } & \text { rope } & \text { tear-PRS.3SG PTCL }\end{array}$

$\begin{array}{llll}\text { jă } а a & j a ̆ r-l-e n, & \text { jastl: } & \text { ol'-l'-em. } \\ \text { together } & \text { tie-PRS-2SG.O } & \text { he.says } & \text { join-PRS-1SG.O }\end{array}$

'When the rope is cut you tie it together, you say, I am joining it up.'

(Ruttkay-Miklián 2010)

\subsubsection{Khanty conjunction $x$ ŏta 'where' + Khanty particle $k i$}

There is another conjunction cooccuring with the particle $k i$, which is $\chi$ ŏta 'where'. There are three such examples in the corpus, and this low number makes it difficult to answer the question whether in these sentences $\chi$ ŏta 'where' should be considered a conditional conjunction, or whether we are dealing with relative clauses in which the particle is present in clause final position due to analogy. Both of the following examples (19)-(20) consist of loosely connected and fragmentary clauses, so it is difficult to categorize them.
soxal ul.

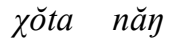
ki wo $\chi-l-a n$,
many-kind board to be-PRS.3SG where you
PTCL cut-PRS-2SG

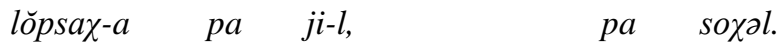

flat-LAT PTCL become-PRS.3SG also board

'There are several types of boards. If you just cut it with an ax like this, and if it is flat as well, that is also a board.'

(Ruttkay-Miklián 2010)

(20)

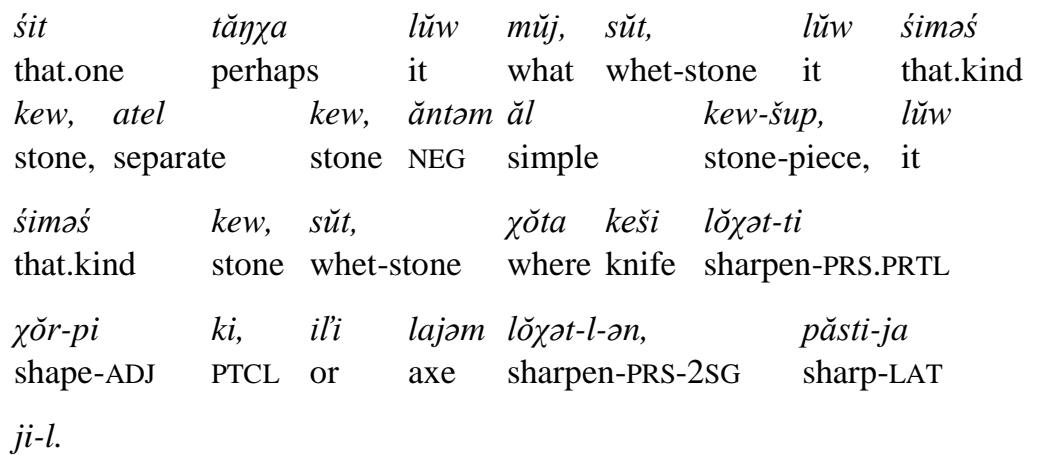

become-PRS.3SG 
'That most likely is a whetstone, a kind of stone, a separate stone, not a simple piece of stone, but a kind of stone, sharpening stone, where/if it is of the form of a whetstone, or you sharpen an ax and it becomes sharp.'

(Ruttkay-Miklián 2010)

The following sentence (21) is, however, appropriate for syntactic evaluation.

(21) (Context: "Hard, hard, that's usually fur, or mostly used when talking about fur. Or the ground is hard, sometimes you cannot dig into it and you say: the ground is hard.")

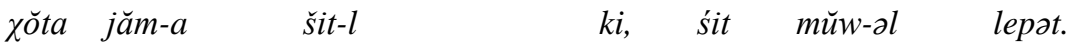
where good-LAT be.possible-PRS.3SG PTCL that earth-3SG soft

'Where it can be [dug] the ground is soft.'

(Ruttkay-Miklián 2010)

As Ruttkay-Miklián confirmed the clause beginning with $\chi$ ŏta could be a relative clause, only if the clause initial śit was sita 'there' (Ruttkay-Miklián personal communication 2015). In that case the original English translation of the sentence would be 'Where it can be [dug], there the ground is soft'. In the given form, it seems to be a conditional sentence 'If it can be dug the ground is soft', which is in accordance with the context, i.e. the speaker had to make clear the word meaning 'hard'. In any case, it should be noted that ki cooccurs with a conjunction other than $\chi \check{o n}$ or jesli, which is not mentioned as a potential source of conditional markers at Heine and Kuteva (2002: 329), so it needs further investigations.

\subsubsection{Khanty $k i$ 'if' as a conjunction $+k i$ 'if' as a particle}

In the protasis of the next sentence, a conjunction and a particle seem to be present at the same time. However, as opposed to the previous sentences, in clause initial position we have the particle $k i$, which is expected to occur in a position any other than this, and appears once more within the same clause in clause final position. This construction may be a mixture of the Russian and Khanty patterns. The primary marker of conditionality, not mentioning paratactic sentences here, is undoubtedly $k i$, which appears not only in one of its traditional positions but also clause-initially, which may be an influence of the Russian language abounding in conjunctions in general. 


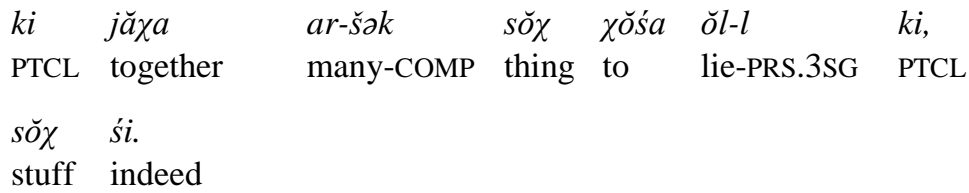

'When more things are lying together, that's stuff, indeed.'

(Ruttkay-Miklián 2010)

As this is the only example of this pattern, it might be a one-time construction, or a slip-of-the-tongue, which is not unusual in spontaneous speech. In RuttkayMiklián's opinion, this construction is hardly acceptable for Khanty speakers (Ruttkay-Miklián: personal communication, 2015).

\subsection{The distribution of various conditional structures}

The above examples (11)-(22) present various formations of conditional sentences, suggesting that, in addition to traditional patterns, sentences displaying MAT or PAT borrowing appear in great quantities. Clearly, in order to judge the actual importance of the innovative types, it is inevitable to know their ratio in the corpus. ${ }^{8}$

First, the number of occurrences of each recent type (11)-(22) concerning the whole corpus will be given (5.5.1). Due to the size of the corpus, the figures referring to the traditional types regarding the whole material will be estimated on the basis of one single file (5.5.2). Then (5.5.3), the proportions will be compared to those of Riese (1984: 102,104), which were calculated on the basis of traditional texts.

\subsubsection{How the individual sentence types are represented in the whole corpus}

The following table displays the actual numbers of sentences presented above, on the basis of the whole corpus (Table 1) (uncertain i.e. fragmented or ill-formed sentences are included in the numbers in brackets):

\begin{tabular}{|l|l|}
\hline $\begin{array}{l}\text { Conjunctions / } \\
\text { conjunction and particle }\end{array}$ & Occurrence \\
\hline jesli.... & 3 \\
\hline$j e s l i \ldots k i$ & $2(3)$ \\
\hline
\end{tabular}

\footnotetext{
${ }^{8}$ As Ruttkay-Miklián's texts are stored in distinct files distinguished by the initials of the entries processed in them, the ratio of the individual sentence types within the whole corpus can be estimated by a rate calculation.
} 


\begin{tabular}{|c|c|}
\hline 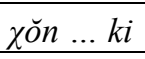 & $5(8)$ \\
\hline 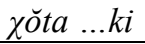 & $2(3)$ \\
\hline$k i \ldots k i$ & 1 \\
\hline Total & $13(18)$ \\
\hline
\end{tabular}

Table 1. Sentences not following traditional Khanty patterns

As can be seen in Table 1, jesli functioning as the only marker of the conditional is documented in only three sentences. As it is combined with the particle $k i$ in three further sentences, jesli occurs in 6 sentences all in all.

\subsubsection{The estimated proportion of traditional sentence types}

Table 2 displays the size of the text (given in number of words) in the $s$-file as well as in the rest of the material.

$\begin{array}{lll} & s \text { - file } & \text { other files } \\ \text { Number of words } & 13,500 & 113,700\end{array}$

Table 2. Number of words in the texts to be compared

On the basis of the actual counts in the $s$-file, the approximate number of sentence types in the whole text can be estimated (Table 3):

\begin{tabular}{|l|l|l|l|}
\hline $\begin{array}{l}\text { Marking of conditional } \\
\text { sentences }\end{array}$ & $\begin{array}{l}\text { s-file } \\
\text { (actual count) }\end{array}$ & $\begin{array}{l}\text { other files } \\
\text { (estimated) }\end{array}$ & $\begin{array}{l}\text { total } \\
\text { (estimated) }\end{array}$ \\
\hline Sentences containing $k i$ & 58 & ca 487 & ca 545 \\
\hline Paratactic sentences & 15 & ca 126 & ca 141 \\
\hline
\end{tabular}

Table 3. Calculated numbers of conditional sentence types

\subsubsection{A comparison of old folklore texts to recent spontaneous speech production}

Last but not least, the proportion of the two types of traditional formation can be compared to the proportions given by Riese (1984: 102, 104). Table 4 summarizes the percentage of the different types of conditional sentences in the texts commenting the dictionary entries beginning with $s$-. 


\begin{tabular}{|l|c|c|c|}
\hline & \multicolumn{2}{|c|}{$\begin{array}{c}\text { Dictionary entries } \\
\text { beginning with s- }\end{array}$} & $\begin{array}{c}\text { Riese } \\
(\mathbf{1 9 8 4})\end{array}$ \\
& Number & $\%$ & $\%$ \\
\hline Particle $k i$ & 58 & 78 & 89 \\
\hline Parataxis & 15 & 20 & 10 \\
\hline Other & 1 & 2 & 1 \\
\hline
\end{tabular}

Table 4. Proportion of the different types of conditional sentences

To sum up, both comparisons show that despite the relatively high number of innovative types, it is still the two traditional sentence types that appear in the great majority of the conditional sentences in question. In other words, from this point of view, Ruttkay-Miklián's speaker can still be qualified as a traditional speaker. Even if the problematic sentences in (15)-(17) as well as the uncertain data are included, the proportion of non-traditional ways of expressing conditional content is not higher than $2 \%$.

\section{Conclusion}

Having surveyed the conditional sentences of the given texts, the questions listed in the introduction can be answered in the following way.

In the texts of a middle-aged bilingual speaker the number of occurrence of the conjunction jesli is much lower than expected considering the surveys reporting jesli to have been borrowed in Khanty by the 1980s.

The informant seems to be a traditional speaker from the perspective of the way she expresses conditional content (the investigation, adapted to the specialities of the corpus, was restricted to conditional sentences referring to general truths). On the one hand, it is because she produces a greater percentage of paratactic sentences than the texts in Riese's investigation (Riese 1984: 102, 104). On the other hand, the particle $k i$, which was the most typical marker of conditional sentences before the intense Russian influence, counts as the most typical one even today. As in many other languages, a double marked conditional sentence (i.e. the simultaneous use of a conjunction and a particle which cannot be in clause initial position) evolved due to favourable syntactic circumstances. However, there are only a small number of sentences of this type. This innovative construction also appears in clauses beginning with conjunctions other than jesli, or Khanty xŏn 'when'. However, on 
the basis of the available examples, it is impossible to define the grammatical function of the $k i$ particle in these sentences.

Concluding on the basis of the above data, the impact of Russian conditional sentences can be observed in both the domains of MAT and PAT borrowings. As for MAT borrowing, the Russian conjunction has appeared in Khanty sentences, although it occcurs quite rarely. PAT borrowing is also possible to detect in the sentences in which the clause of protasis contains or actually begins with a conjunction of Khanty origin, i.e. the changes in syntax cannot be said to be the consequence of borrowing jesli from Russian. Besides, the overwhelming majority of the conditional sentences produced by the speaker do follow the two traditional patterns, i.e. paratactic subordinate sentences and the ones in which conditional content is marked by a particle.

\section{Abbreviations}

$\begin{array}{ll}\text { ACC } & \text { accusative } \\ \text { ADJ } & \text { adjective } \\ \text { COMP } & \text { comparative } \\ \text { F } & \text { feminine } \\ \text { FUT } & \text { future } \\ \text { IMP } & \text { imperative } \\ \text { INF } & \text { infinitive } \\ \text { LAT } & \text { lative } \\ \text { LOC } & \text { locative } \\ \text { M } & \text { masculine } \\ \text { NEG } & \text { negative } \\ \text { O } & \text { objective conjugation } \\ \text { PASS } & \text { passive } \\ \text { PL } & \text { plural } \\ \text { PPOS } & \text { postposition } \\ \text { PREV } & \text { preverb } \\ \text { PRS } & \text { present }\end{array}$

PRS.PRTL present participle

PST past

PST.PRTL past participle

PTCL particle

PURP purpose 
RU Russian

SG singular

\section{References}

Aikhenwald, Alexandra Y. 2008. Grammars in contact: A cross-linguistic perspective. In: Aikhenwald, Alexandra Y. and Dixon, R. M. (eds) Grammars in contact. Oxford: Oxford University Press.

Alvre, Paul 1983. Vene laenudest uurali keelte konjunktsioonides. In: Janhunen, Juha; Peräniitty, Anneli and Suhonen, Seppo (eds.) Mémoires de la Société Finno-Ougrienne 185: 25-50.

Bakró-Nagy, Marianne 2006. Grammatikai kölcsönzés és grammatikalizáció. A komi feltételes ke partikula a manysiban. (Grammatical borrowing and grammaticalization: The Komi conditional particle ke in Mansi]. In: Sipos, Mária (ed.) Obi-ugorok a 21. században [Ob-Ugric peoples in the 21st century] (CD). Budapest: MTA Nyelvtudományi Intézet

Bakró-Nagy, Marianne 2008. Conditional constructions in Uralic. http://www.univie. ac.at/urtypol/bakro.pdf [Accessed: March 2015]

Ethnologue $=$ http://www.ethnologue.com/country/RU/languages [accessed: March 2015]

Grenoble, Lenore A. 2000. Morphosyntactic change: The impact of Russian on Evenki. In: Gilbers, D. G., Nerbonne, J.and Schaeken, J. (eds.) Languages in contact. Amsterdam: Rodopi. 105-120.

Grenoble, Lenore A. 2012. Areal typology and syntactic change. Вестник ТГПУ (TSPU Bulletin) 2012 (1): 101-104.

Hajek, John 2008. Language contact and convergence in East Timor: The case of Tetun Dili. In: Aikhenwald, Alexandra Y. and Dixon, R. M. (eds.) Grammars in contact. Oxford: Oxford University Press. 163-178.

Khomlyak 2002. = Хомляк, Л. Р. Арем-моньщээм ел ки манл... Если моя сказкапесня дальше идёт... [If my song, my tale goes on...] Ханты-Мансийск: Групп Полиграфист.

Jefremova, Tatyjana 2013. Mondattani kontaktusszerkezetek megítélése és használata városi marik beszédében. In: Csepregi, Márta; Kubínyi, Katalin, and Siivonen, Jari (eds.) Grammatika és kontextus. Új szempontok az uráli nyelvek kutatásában 3. [Grammar and context: New perspectives in research into the Uralic languages, vol. 3]. Budapest: Eötvös Loránd Tudományegyetem, Finnugor Tanszék. 181-193. 
Kaysina, Inna 2013. The adoption of Russian conjunctions in Udmurt. Journal of Estonian and Finno-Ugric Linguistics 4 (2): 131-144.

Leinonen, Marja 2002. Influence of Russian on the syntax of Komi. FinnischUgrische Forschungen 57: 195-358.

Majtinskaja 1983. = Майтинская, К. Е. Заимствованные служебные слова в финно-угорских языках. In: Janhunen, Juha; Peräniitty, Anneli and Suhonen, Seppo (eds.) Symposium saecularae Societatis Fenno-ugricae. Mémoires de la Société Finno-Ougrienne 185: 179-188.

Mitrevski, George: Conditional mood. http://www.auburn.edu/ mitrege/russian/tutorials/0048.html [Date of access: March 2016]

Pápay, József 1910. Északi-osztják nyelvtanulmányok. [Northern Khanty linguistic studies]. Budapest: Magyar Tudományos Akadémia.

Rédei, Károly 1968. Nordostjakische texte (Kazym-Dialekt) mit Skizze der Grammatik. Göttingen: VandenHoeck and Ruprecht.

Riese, Timothy 1984. The conditional sentence in the Ugrian, Permian and Volgaic languages. Studia Uralica 3. Wien: Verband der wissenschaftlichen Gesellschaften Österreichs (VWGÖ).

Rießler, Michael 2007. Grammatical borrowing in Kildin Saami. In: Matras, Yaron and Sakel, Jeanette (eds.) Grammatical borrowing in cross-linguistic perspective. Berlin: Mouton de Gruyter. 31-74.

Ruttkay-Miklián, Eszter 2008. The dialect spoken by Roza Makarovna. http://hantisirn.nytud.hu/sites/default/files/Dialect\%20of \%20Roza\%20Makarovna2.pdf. Date of access: March 2016.

Ruttkay-Miklián, Eszter 2010. Synya Khanty dictionary by Roza Makarovna. Manuscript.

Sakel, Jeanette 2007a. Language contact between Spanish and Mosetén. A study of grammatical integration. International Journal of Bilingualism 11 (1): 25-53.

Sakel, Jeanette 2007b. Types of loan: Matter and pattern. In: Matras, Yaron and Sakel, Jeanette (eds.) Grammatical borrowing in cross-linguistic perspective. Berlin: Mouton de Gruyter. 15-31.

Schmidt Éva 2008. Északi osztják nyelvtani jegyzet (serkáli nyelvjárás) [Northern Khanty grammar (Sherkaly dialect)]. In: Fejes, László (ed.) Serkáli osztják chrestomathia [Sherkaly Khanty chrestomathy]. Schmidt Éva Könyvtár 3. Budapest: MTA Nyelvtudományi Intézet. 13-75. 
Sipos Mária 2014. Célhatározói mondatok idiolektális variánsai egy hanti-orosz kétnyelvü beszélö szövegeiben [Intraspeaker variants of purpose clauses in the texts of a Khanty-Russian bilingual speaker]. Nyelvtudományi Közlemények 110: 79-97.

Steinitz, Wolfgang 1975. Ostjakologische Arbeiten. Band I: Ostjakische Volksdichtung und Erzählungen aus zwei Dialekten. Texte. Budapest: Akadémiai Kiadó.

Steinitz, Wolfgang 1966-1988. Dialektologisches und etymologisches Wörterbuch der ostjakischen Sprache. Berlin: Akademie Verlag.

Tánczos Orsolya 2013. Hogy... hogy? Kettős kötőszók az udmurt mondatban [How come? Double conjunctions in Udmurt sentences]. In: Agyagási, Klára; Hegedűs, Attila and É. Kiss, Katalin (eds.) Nyelvelmélet és kontaktológia 2 [Linguistic theory and language contact 2]. Piliscsaba: PPKE BTK Elméleti Nyelvészeti Tanszék - Magyar Nyelvészeti Tanszék. 95-112.

Thráinsson, Höskuldur 2013. Ideal speakers and other speakers: The case of dative and other cases. In: Fernández, Beatriz and Etxepare, Ricardo (eds.) Variation in datives: A micro-comparative perspective. Oxford Studies in Comparative Syntax. Oxford: Oxford University Press. 161-188.

Veltmann, Frank 1994. Conditionals. In: Asher, R. E. and Simpson, J. M. Y. (eds.) The encyclopedia of language and linguistics. Oxford and New York: Pergamon Press.

Wade, Terence 2011. A comprehensive Russian grammar. Oxford: Wiley and Blackwell. 